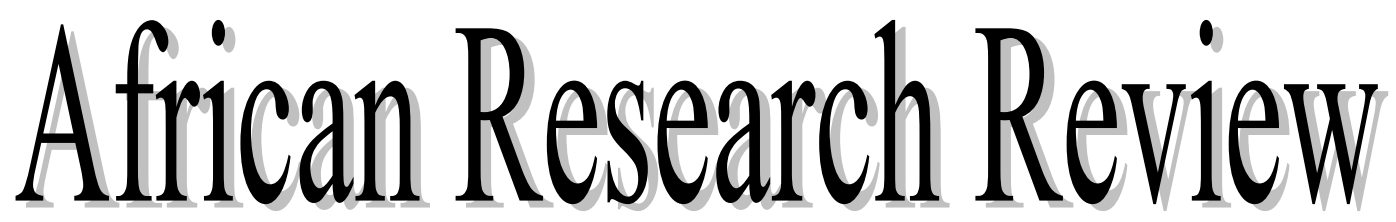

AN INTERNATIONAL MULTI-DISCIPLINARY JOURNAL, BAHIR DAR, ETHIOPIA

AFRREV VOL. 11 (3), SERIAL NO. 47, JULY, 2017: 105-114

ISSN 1994-9057 (Print)

ISSN 2070-0083 (Online)

DOI : http://dx.doi.org/10.4314/afrrev.v11i3.11

\title{
Differentiating Instruction in Early Childhood Care Education: Teachers' Practice
}

\author{
Afurobi, A. 0. \\ Department of Curriculum \& Instruction \\ Alvan Ikoku Federal College of Education, Owerri, \\ E-mail: afurobiadaku@yahoo.com \\ Phone: +2348033330812
}

Izuagba, A. C.

Department of Curriculum and Instruction

Alvan Ikoku Federal College of Education, Owerri

Ifegbo, $\mathbf{P} . \mathbf{C}$.

Department of Curriculum \& Instruction

Alvan Ikoku Federal College of Education, Owerri

Opara, J. M.

Department of Early Child Care Education

Alvan Ikoku Federal College of Education, Owerri

\begin{abstract}
Differentiated instruction involves altering the implementation and design of the lesson and activities so that the needs of all children are met. Through it children use different pathways to explore and learn while taking away the same essential ideas and understanding on the content. The study sought to determine teachers'/caregivers practice in differentiating instruction in pre-primary classrooms in Owerri educational zone of Imo state. This descriptive survey is guided by three research questions and
\end{abstract}

Copyright (C) International Association of African Researchers and Reviewers, 2006-2017: 
two hypotheses. Population comprised all teachers/caregivers in the government approved preprimary schools totaling 119 . This number was purposively sampled. Instrument was a validated 17-item questionnaire and data generated were analysed using grand mean, percentages and chi square. Results show that teachers' practice was very poor. Years of experience had influence on their practice but location did not. Recommendations made among others include the need to mount retraining and retooling programmes to improve teachers'/caregivers practice in differentiating instruction at this foundation level.

Key words: childhood education, Differentiated instruction, teachers/ caregivers' practice

\section{Introduction}

Early childhood education is recognized by the Federal Government of Nigeria and is the foundation of education for later years. It is an accepted fact that education at this level is very important because children experience cognitive, language, perceptual, socio-economic and motor development which they will need for excelling later in life (Akinrotimi \& Olowe, 2016). Estes (2004) described the early years as a remarkable period of growth and development in the lives of children. Oduolowu \& Oluwe (2011) noted that the early years of children are years of extreme vulnerability and tremendous potentials, during which adequate protection, care and stimulation are essential to provide the foundation for well-being and development. The provisions for this foundation are therefore very critical to ensure that the later years are properly anchored.

Seeing the importance of these years in a child's life, it has become mandatory that teachers/caregivers employ appropriate strategies in the teaching learning process. Before this can be done, it behoves the teachers to understand that children are unique individuals that have come to the classroom with different knowledge and skill levels (Izuagba, Afurobi \& Ifegbo, 2016). Each child's learning style can be likened to the uniqueness of individual fingerprint. Therefore, they neither learn the same way nor share the same level of ability. These have made it imperative that teachers tailor learning experiences to differentiate among individual needs of students in the classroom. By one size fit all approach to teaching and learning the individuality of the children are negated. Since successful instruction at all levels of education, must respect individual differences, it follows that teachers/caregivers at this foundation stage must learn to build into the instructional procedure the individual needs and interest of each child (Izuagba, et al. 2016). This arduous task can be achieved through differentiated instruction.

Differentiated instruction has been defined by several authors as a philosophy of teaching and learning that recognizes and responds to students' differences in readiness, interests and learners' profiles or styles (Tomlinson, 2001; Tomlinson et al, 2003; Purcell, 2007, Weselby, 2014; Izuagba et al. 2016). Put differently, differentiated instruction involves altering the implementation and design of the lesson and activities so that the needs of all children are met. Through it children use different pathways to explore and learn while taking away the same essential ideas and understanding on the content. Tomlinson (2000) insisted in Subban (2006) that this philosophy of teaching

Copyright (ㅇ International Association of African Researchers and Reviewers, 2006-2017: www.afrevjo.net.

Indexed African Journals Online: www.ajol.info 
is based on the premise that students learn best when their teachers accommodate the differences in their readiness level, interests and learning profiles/styles (p. 940).

Today's classrooms are more diverse than ever. With these changes comes the challenge of meeting the diverse needs of students. Diversity includes aspects of; age, ethnicity, gender, physical abilities, religious orientation, socio-economic status, family Status etc. All these diversities within a classroom require teacher's attention to minimize the probable reasons for slow learning.

Teachers struggle with ways of meeting all children's need in the classroom. This is in addition to keeping the physical space, social and emotional environment of all classroom appropriate, to ensure that children learn at their highest potential. Reason behind teacher's struggle is the fact that learners are from age three with some having developmental delays therefore prone to behavioural issues as well as a variety of other needs such as physical handicaps etc. Inclusive education is often practiced at this level of education for the primary reason of accessibility.

The Universal Basic Education (UBE) is free and compulsory with the caveat that no child should be left behind. This imperative has made it of great importance that teachers/caregivers need to possess an extensive repertoire of skills and strategies to draw from, know how and when to choose among them to effectively promote each child's learning and development. These strategies include but not limited to acknowledging, encouraging, giving specific feedback, modelling, demonstrating, adding challenge, giving clues or other assistances, providing information and giving directions (National Association for the Education of Young Children, n.d., pp. 18-19; Tk California, n.d.).

According to Tomlinson, teachers can differentiate instruction through four ways; Content, Process, Product and Learning environment. Teachers who practice differentiation in the classroom design lessons based on students' learning styles, group students by shared interests, topic or ability for assignments, assess students learning using formative assessment. Manage the classroom to create a safe and supportive environment as stipulated by the Child Rights Act (Izuagba, Afurobi \& Jeremiah, 2014), continually assess and adjust lesson content to meet student's needs (Weselby, 2014). Purcell (2007) believes that teachers who successfully differentiate instruction are sensitive to the developmental differences among children. For Purcell, they regularly monitor children's progress in order to modify instruction and meet each child's needs. Instruction is based on established learning goals, child assessment and observations. Whole-group instruction is minimized and teachers spend more time working with children in small groups and individually (p1).

TK California (n.d) gives the following examples as differentiated instruction strategies thus:

- Flexible grouping that considers strengths and room for growth of all children.

- Exploration/hands-on centres or stations where children are responsible for their own learning

- Directions that are short and concise

- Questioning techniques that enable answers based on each student's readiness and comprehension and

Copyright $\left({ }^{\circ}\right.$ International Association of African Researchers and Reviewers, 2006-2017: www.afrrevjo.net.

Indexed African Journals Online: www.ajol.info 
- Children as well as teacher initiated tasks and projects that provide for handson learning.

For TK California, teachers may need to look at breaking skills down into sequential steps such as:

- The time for individual students to complete tasks;

- The content and degree of support

- The scaffolding based on the students' assessed need; and

- Approaches to support self-help and social emotional competencies.

Weselby (2014) reported Wilson's study of differentiating instruction among preschoolers and found that it was the most effective strategy, showing a higher rate of retention among children. It was also found to ensure that children were engaged in discussion and on task, practicing after exposure to content and teaching others. Weselby therefore, posited that whether teachers are differentiating content, process, products or learning environment the use of ongoing assessment and flexible grouping makes this a successful approach to instruction. Corleys' (2005) study also pointed to the success attained from the use of differentiated instruction. For him observation and assessment of student's skills and progress are key components of differentiated instruction. Using assessment to differentiate instruction helps children succeed in transitional kindergarten and build the strong foundation that will ultimately prepare them for meeting the kindergarten standards. Evidence from formative assessment leads naturally to differentiated instruction and flexible grouping; which is why feedback from formative assessments enables the teacher to tailor learning is to meet children where they are, adding just enough challenge so that a task goes a bit beyond what they can already do.

\section{Theoretical Framework: Social Constructivist Theory}

Differentiated instruction relies heavily on the social constructivist theory by Vygotsky (1978) in which children work at their "zone of proximal development" (ZPD). The ZPD is just the right gap between what the child can do independently and what he/she is newly learning. Formative assessment provides evidence and guidance in finding the "zone" for each child. The goal of differentiated instruction is to provide scaffolding or temporary support to guide children from what they already know to what they can do next. Teachers can then gradually remove the scaffolding, reducing the support as the child designs to master the skill and prepares to move to his/her next step. By working in smaller, more flexible groups, teachers strive to teach within each child's optional learning level or zone of proximal development (ZPD). ZPD is based on the understanding that learning will not occur at its optimal level if children are not challenged enough (Tomlinson et al. 2003) or if they are over challenged and frustrated (Kapsrick \& Hauslein, 2001).

Differentiated instruction is not new to teaching at the preschool level since the children are exposed to the play way method. The issue is whether play is structured to ensure that children's diversities are considered and content, process, product and learning environment are differentiated in the teaching learning situation. It is against this background that the researchers sought to determine teachers'/caregivers practice in differentiating instruction at the early childhood care education in Owerri educational

Copyright $\left({ }^{\circ}\right.$ International Association of African Researchers and Reviewers, 2006-2017: www.afrrevjo.net.

Indexed African Journals Online: www.ajol.info 
zone. The study will specifically determine the influence of location and years of experience on teachers practice.

\section{Research Questions}

The following research questions guided the study:

1. What is the mean difference in teachers/caregivers' practice in differentiating instruction at the early childhood care education?

2. To what extent does location influence teachers/caregivers' practice in differentiating instruction at the early childhood care education?

3. To what extent do years of experience influence teachers/caregivers' practice in differentiating instruction at the early childhood care education?

\section{Hypotheses}

1. There is no significant difference between urban and rural teachers/caregivers' practice in differentiating instruction at the early childhood care education.

2. There is no significant difference in teachers /caregivers' practice in differentiating instruction at the early childhood care education based on years of experience.

\section{Methods}

This study is a descriptive survey designed to elicit information on teachers practice in differentiating instruction at the early childhood care education the population comprises all teachers'/caregivers in government approved pre-primary schools in Owerri educational zone totalling 119 . The purposive sampling was employed in which the whole teachers/caregivers were used as the sample size.

Instrument was a 17-item questionnaire structure on a four-point scale with options provided as very large extent (VLE), large extent (LE), very low extent (VLE) and low extent (LE). Respondents were made to select the option that best describes their practice in differentiating instruction. The instrument was validated by two experts in differentiated instruction and one from educational measurement and evaluation. Their corrections were effected in the final draft. Instrument was tested for reliability with the test retest method using twenty respondents outside the study population. Data generated was analysed using Pearson's Product Moment Correlation Coefficient which yielded 0.87 . This index was judged to be high signifying that the instrument is reliable.

Instrument was administered on a face to face basis with the help of two assistants. This ensured a $100 \%$ return rate. Data generated were analysed with grand mean, percentages and chi square test of independence. 2.5 was used as the reference mean.

\section{Result}

Research Question 1: What is the mean difference in teachers/caregivers' practice in differentiating instruction at the early childhood care education (ECCE)?

Copyright (C) International Association of African Researchers and Reviewers, 2006-2017: www.afrrevjo.net. 
Table 1: Mean responses on teachers/caregivers' practice in differentiating Instruction at the ECCE

\begin{tabular}{llllllll} 
S/N & ITEMS & VHK & HK & LK & VLK & $X$ & \\
\hline
\end{tabular}

I do the following during instruction:

Group children based on their:

1. Interest

2. Readiness Level

3. Learning styles

68

$$
40
$$

62

differentiate content by;

4. Providing different sources of the same content

5. Allowing learners their preferred source(s) based on interest and learning styles

6. Provide some content in different forms like visual, audio, graphics

7. Using different methods and strategies while teaching e.g. group work, project, Jigsaw

8. Using flexible grouping during lessons to ensure participation of all children.

9. Giving children opportunity to initiate tasks /activities during lesson.

I differentiate product by;

10. Allowing children to demonstrate learning through drawing, rubrics, demonstrations etc.

I differentiate the learning environment by;

11. Using more assessment for learning than in 4045 learning

12. Using rubrics to enable children contribute during assessment

13. Using portfolio to enable children and 180 parents monitor their progress

I use the following strategies

14. Monitoring children's progress regularly

\begin{tabular}{ccccc}
112 & 45 & 60 & \multicolumn{1}{c}{46} & 2.2 \\
116 & 75 & 60 & 35 & 2.4 \\
44 & 63 & 86 & 44 & 1
\end{tabular}

15. Providing explorative activities

16. Providing scaffolds based on children's assessed needs

17. Altering the implementation and design of learning activities to meet all children's needs.

Copyright () International Association of African Researchers and Reviewers, 2006-2017: www.afrrevjo.net. 
The above table shows the mean responses of respondents practice in differentiating instruction at the ECCE with a grand mean of 2.1. The conclusion is that teachers'/caregivers practice in differentiating instruction is to a low extent.

Research Question 2: To what extent does location influence teachers' practice in differentiating instruction at the early childhood care education?

Table 2: Percentage response on influence of location on teachers' practice in differentiating instruction at the early childhood care education.

\begin{tabular}{lllcll}
\hline LOCATION & FVLE $\%$ & FLE\% & FVLE\% & FLE\% & FTOTAL\% \\
\hline Urban & $8(6.7)$ & $7(5.9)$ & $15(12.6)$ & $26(22)$ & $56(47)$ \\
Rural & $11(9.3)$ & $14(11.7)$ & $20(16.8)$ & $18(15)$ & $63(53)$ \\
Total & $\mathbf{1 9 ( 1 6 )}$ & $\mathbf{2 1 ( 1 7 . 6 )}$ & $\mathbf{3 5 ( 2 9 . 4 )}$ & $\mathbf{4 4 ( 3 7 )}$ & $\mathbf{1 1 9}(\mathbf{1 0 0 )}$ \\
\hline
\end{tabular}

The above table shows that 8 or $6.7 \%, 75.9 \%, 152.6 \%$ and 26 or $22 \%$ of urban teachers/caregivers' practice in differentiating instruction at the ECCE with very large respectively while $11 \mathrm{n}$ or $9.3 \%, 14$ or $11.7 \%, 30$ or $16.8 \%$ and 18 or $15 \%$ of rural respondents, very little extent and little extent respectively. The conclusion is that location is not implicated in teachers'/caregivers practice.

Research Question 3: To what extent do year of experience influence teachers' practice in differentiating instruction at the early childhood care education.

Table 3: Responses on influence of years of experience on teachers practice in differentiating instruction at the early childhood care education.

\begin{tabular}{llllll}
\hline $\begin{array}{l}\text { Years of } \\
\text { Experience }\end{array}$ & ${ }_{\mathbf{F V L E}} \%$ & FLE $\%$ & FVLE $\%$ & ${ }_{F} \mathbf{L E} \%$ & FTOTAL\% \\
\hline $5-10$ & $6(5)$ & $5(4.2)$ & $17(14.3)$ & $29(24.3)$ & $57(48)$ \\
$11+$ & $13(11)$ & $16(13.4)$ & $18(15.1)$ & $15(12.6)$ & $62(52)$ \\
Total & $\mathbf{1 9}(\mathbf{1 6 )}$ & $\mathbf{2 1}(\mathbf{1 7 . 6})$ & $\mathbf{3 5}(\mathbf{2 9 . 4 )}$ & $\mathbf{4 4}(\mathbf{3 7})$ & $\mathbf{1 1 9}(\mathbf{1 0 0})$ \\
\hline
\end{tabular}

The above table shows that a total of 35 or $29.4 \%$ and 44 or $37 \%$ of all teachers/caregivers irrespective of their years of experience practiced at very little extent and little extent respectively. The conclusion is that years of experience are not implicated in teachers/caregivers practice of differentiating instruction at the ECCE.

\section{Test of Hypotheses}

Hypothesis I: There is no significant difference between urban and rural teachers' practice in differentiating instruction at the early childhood care education 
Table 4: Chi square test on urban and rural practice in differentiating instruction at the early childhood care education

\begin{tabular}{lccccccccc}
\hline LOCATION & VLE & LE & VLE & LE & TOTAL & $\mathbf{X}^{2}$ Cal & $\mathbf{X}^{\mathbf{2} 0.05}$ & DIFF. & DECISION \\
\hline Urban & 8 & 7 & 15 & 26 & 56 & & & & \\
Rural & 11 & 14 & 20 & 18 & 63 & 4.58 & 7.82 & 3 & Significant \\
Total & $\mathbf{1 9}$ & $\mathbf{2 1}$ & $\mathbf{3 5}$ & $\mathbf{4 4}$ & $\mathbf{1 1 9}$ & & & & \\
\hline
\end{tabular}

Since $\mathrm{X}^{2} \mathrm{Cal}=4.58$ is less than $\mathrm{X}^{2} 0.05=7.82$, we accept the null hypothesis and conclude that there is no significant difference between urban and rural teachers' practice in differentiating instruction at the early childhood care education.

Hypothesis 2: There is no significant difference in teachers' practice in differentiating instruction at the early childhood care education based on years of experience.

Table 5: Chi Square test on teachers' practice in differentiating instruction at the early childhood care education based on years of experience.

\begin{tabular}{lccccccccc}
\hline $\begin{array}{l}\text { Years of } \\
\text { Experience }\end{array}$ & VLE & LE & VLE & LE & Total & $\mathbf{X}^{\mathbf{2}}$ cal & $\mathbf{X}^{\mathbf{2} 0.05}$ & df. & Decision \\
\hline $5-10$ & 6 & 5 & 17 & 29 & 57 & & & & \\
$11+$ & 13 & 16 & 18 & 15 & 62 & 18.11 & 7.82 & 3 & Significant \\
Total & $\mathbf{1 9}$ & $\mathbf{2 1}$ & $\mathbf{3 5}$ & $\mathbf{4 4}$ & $\mathbf{1 1 9}$ & & & & \\
\hline
\end{tabular}

Since $\mathrm{X}^{2} \mathrm{Cal}=18.11$ is greater than $\mathrm{X}^{2} 0.05=7.82$ at degree of freedom 3 , we reject null hypothesis and conclude that there is a significant difference in teachers' practice in differentiating instruction at the early childhood care education based on years of service. The result is in favour of teachers with $11+$ years of experience.

\section{Discussion}

This discussion is based on the result derived from 119 teachers/caregivers in ECCE in Owerri educational zone. Result shows that respondents do not practice differentiated instruction at this level of education in spite of its importance in early childhood care. The grand mean of 2.1 was found to be less than the reference mean of 2.5 , we therefore conclude that teachers/caregivers practice differentiated instruction to a very low extent. This has very serious implication for the teaching and learning at this level where foundation is laid to cater for what happens to pupils later in primary and secondary school level. Weselby (2014) insisted that differentiating instruction and using flexible grouping makes differentiation a very successful approach for early childhood care education. This draws attention to the need to constantly remind teachers/caregivers on the vital nature of differentiating instruction especially in catering to readiness, learning style and interest of children.

In answer to research questions two and three respondents showed very low level of practice and location and years of experience did not change or affect their practice with 35 or $29.4 \%$ having very little extent as their responses. The responses for little

Copyright (C) International Association of African Researchers and Reviewers, 2006-2017: www.afrevjo.net.

Indexed African Journals Online: www.ajol.info 
extent were also high with 44 or $37 \%$. The calculated Chi square 4.58 was found to be less than the critical value of Chi 7.82 at degree of freedom 3 (Table 4) on location. Null hypothesis was therefore accepted and upheld and the conclusion is that there is no significant difference between urban and rural teachers/caregivers' practice in differentiating instruction at ECCE. This finding supports the result in table 2 and shows that location is not a determining factor of teachers/caregivers practice.

An interesting development followed when the same data for years of experience were subjected to Chi square test (Table 5) The Chi square result showed the $\mathrm{X}^{2} \mathrm{cal} 18.11$ to be greater than the $X^{2} 0.05=7.82$ at degree of freedom 3 . The null hypothesis was rejected and the conclusion is that there is a significant difference in teachers/caregivers practice in differentiating instruction at the ECCE. The result seems to be in favour of respondents with 11+ years of experience. One may further conclude that years of experience is a factor in determining teachers/caregivers practice in differentiating instruction. These results seem to support Izuagba et al's (2016) assertion that teachers struggle with ways in meeting the diversity that is found in today's classroom which require attention to minimize probable slow learning. Teachers with more experience seem to be more aware of these diversities and often try to handle them unlike novice teachers.

\section{Conclusion}

The need to integrate differentiation of content, process, product and learning environment cannot be over emphasized given the level of diverse learners in the 21st century. To adequately lay proper foundation for later schooling differentiate instruction must be integrated and used. Unfortunately, the results of this study revealed that:

- teacher/caregivers' practice is to a very little extent;

- location is not a determining factor of teachers practice and;

- years of experience are a determining factor of teachers practice.

\section{Recommendations}

From the findings of this study, the following recommendations are made thus:

i. A retraining and retooling programme should be mounted to improve teachers/caregivers practice in differentiating instruction at this foundation level.

ii. More resources should be incorporated to enhance and meet the requirements for differentiated instruction.

iii. Teachers/caregivers should be encouraged by the heads of their schools to be more resourceful in using locally made instructional materials to cater to the diverse learning needs of children.

\section{References}

Akinrotimi, A. A., \& Oluwe, P. K. (2016). Challenges in implementation of early childhood education in Nigeria: The way forward. Journal of Education and Practice. 7 (7), 33-38.

Copyright (ㅇ International Association of African Researchers and Reviewers, 2006-2017: www.afrrevjo.net. 
Corley, M. (2005). Differentiated instruction: Adjusting to the needs of all learners. Connecting Research to Practice, 7(c), 21-25.

Estes, L.S. (2004). Essentials of child care and early education. United States of America; Pearson Education Inc.

Oduolowu, E. A., \& Oluwe, P. K. (2011). Government provision of early childcare and education to pre-school orphans in orphanages in Ibadan municipality. Research in Curriculum Studies 6(2)

Izuagba, A. C., Afurobi, A. O., \& Ifegbo, P. C. (2016). Constructivism: The pedagogy for the 21st century classrooms. Owerri: Cel-Bez Publishing.

Izuagba, A. C., Afurobi, A. O., \& Jeremiah, S. (2014). Theory and practice of child friendly schools in Nigeria. Owerri: Cel-Bez Publishing.

Kapunsnick, R. A., \& Hauslein, C. M. (2001). The silver cup of differentiated instruction. Kappa Delta Pi Record, 37 (4), 156-159.

Lipson, M. Y., \& Wixson, K. K. (2009). Assessment in instruction of reading and writing difficulties: An interactive approach (4th ed.). Boston: Pearson Education Inc.

National Association for the Education of Long Children NAEYC (n.d). Position statement on developmentally appropriate practice, pp 18-19.

Purcell, T. (2007). Differentiating Instruction in the preschool classroom. Retrieved 10th February, 2016 from www.stcloudstate.edu/tpi/teachersupport/... /differentiatinginstruction-early childhood.p...

Subban, P. (2006). Differentiated instruction: A research basis. International Educational Journal 7(7), 935-947.

TK California (n.d.). Differentiated instruction. Retrieved 10th February, 2016 from www.tkcalifornia.org/teaching-tools/classroom-instructional.../diffrentiated.html

Tomlinson, C.A. (August, 2001). Differentiation of instruction in the elementary grades. ERIC Digest, ERIC Clearinghouse on elementary and early childhood education.

Tomlinson, C. (1999). Mapping a route to differentiated instruction. Educational Leadership 57(1), 12-16.

Tomlinson, C. A., Brighton, C., Herberg, H., Callahan, C. M., Moon, T. R., Brimijoin, K., et al., (2003). Differentiated instruction in response to student readiness, interest and learning profile in academically diverse classrooms. A review of literature. Journal for the Education of the Gifted. 17(2/3), 119-145.

Vygostsky, L. S. (1978). Mind in society. The development of higher psychological processes. Cambridge MA: Harvard University Press.

Weselby, C. (2014). Teaching strategies. Retrieved 10th February, 2016 from www.stcloudstate.edu/tpi/tchersupport/.../differentiatinginstructionearlychildhood.p....

Copyright $\left({ }^{\circ}\right.$ International Association of African Researchers and Reviewers, 2006-2017: www.afrrevjo.net.

Indexed African Journals Online: www.ajol.info 